\title{
IUCN Meetings in Zaïre
}

The 12th General Assembly of The International Union for Conservation of Nature and Natural Resources, held in Zaïre in September 1975, will be remembered as the occasion when 'worker participation' was accepted. Never before have the ordinary delegates played so great a part in the proceedings or had so great an influence on decisions. This may have meant more headaches for the Board; it certainly meant a smoother run in the open meetings and more satisfied delegates at the end. It was well known before the Assembly that there was discontent about the running of IUCN, both in developing countries in Africa and Latin America and in several western countries, notably the USA and UK. But the key decision of the Programme and Budget Committee to put its draft proposals before an open meeting for general discussion enabled all to have their say. Many constructive suggestions and criticisms were made, and the final document was accepted with very little alteration. Many delegates returned home a great deal happier.

Very striking, too, was the contribution made by the delegates from developing countries - India, Africa, Latin America, Indonesia. There was a complete feeling of equality - developing nations might be short of money, but they are catching up on expertise. Their reports of the conservation work going on in their countries showed that nature conservation had become accepted, good work is being done and progress made. Moreover they have new ideas to contribute as a result of their many difficult social problems, and it was from Africa that the lead came to introduce into the IUCN Programme the important concept that conservation measures can only be carried with the consent of the people affected, that the interests of local and indigenous people not only have to be taken into account but are paramount. The dangers and even disasters that have resulted from ignoring this are exemplified in the widespread poaching of animals in national parks; all too often these parks, for example in Africa, are regarded as playgrounds for the white man imposed on the indigenous people without consultation. In future all IUCN projects will make provision for local participation.

In his opening address to the Assembly the President, Dr Donald Kuenen, declared that in future 'the main thrust of the Union would be through the Commissions'. This means through the voluntary contribution, for IUCN's distinctive character as an international body lies in the role of the six commissions, manned entirely by volunteers from all over the world-scientists, naturalists, conservationists - who provide expert advice, local information and dedicated enthusiasm. The Survival Service Commission (SSC) and the National Parks and Protected Areas Commission are the two that are most concerned with wildlife conservation, and in future it is hoped that these two will work more closely together - one joint meeting was held in Zaïre. In addition it is proposed to regionalise the Commissions, so that, e.g., problems in Latin America will be discussed in the first place by a Latin American Committee meeting in Latin America, instead of, as at present, by a central Commission usually meeting in Switzerland.

The Chairman of the SSC remains our FPS Chairman, Sir Peter Scott, with John Perry (USA) and M. K. Ranjitsinh (India) as deputy chairmen; our FPS Hon. Secretary Richard Fitter is Chairman both of the SSC's small Steering 
A GAME GUARD in the Virunga National Park receives his medal for distinguished service from Citizen Kayinga Onsi Dal, Zaî́re's Minister for Agriculture, during the park's golden jubilee celebrations attended by many IUCN delegates. The park was established as the Albert National Park by the Belgian Government in 1925. A bronze plaque to commemorate 23 guards killed defending the park during the fighting following independence, presented by WWF, was unveiled in the presence of IUCN delegates, Peter Jackson

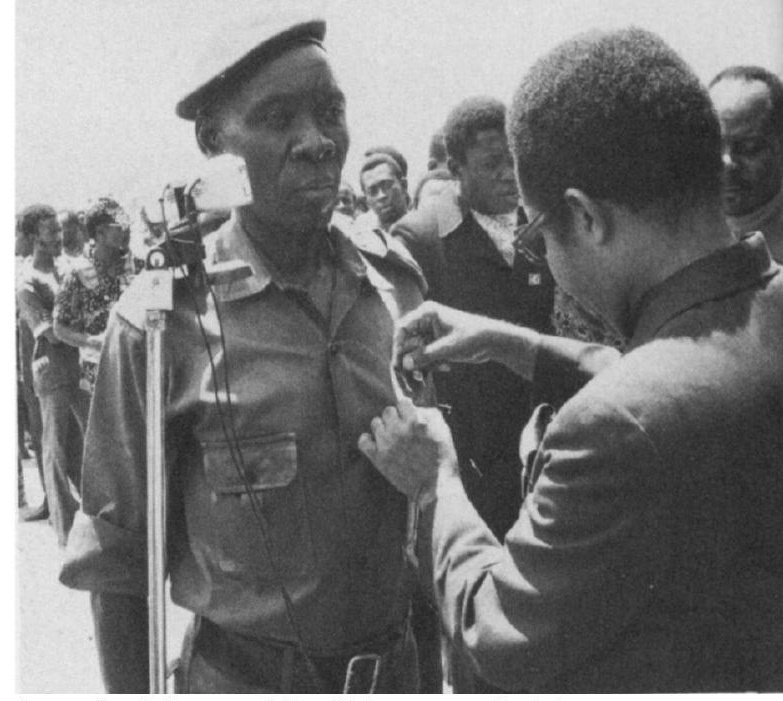

Group and of the Advisory Panel on the Mammal Red Data Book. The Acting Chairman of the National Parks and Protected Areas Commission is Theodor R. Swem (USA), with three Vice-Chairmen: Dr Marc Dourojeanni (Peru), P. H. C. Lucas (New Zealand) and Dr P. M. Olindo (Kenya).

In the course of the Assembly the Director General Dr Gerardo Budowski announced that he was not standing for re-election, and the Assistant Director, Frank G. Nicholls, is due to retire early in 1976. Dr R. F. Dasmann has been appointed Acting Director and new appointments are to be made early in 1976. An extra meeting of the General Assembly will be held in Europe, probably at Bonn, in January 1977, to consider the new appointments and reorganisation.

The Technical Meetings which occupied five days in the middle of the Assembly covered a wide range (some thought too wide) under the general title Conservation for the Decision Makers, a title that was warmly welcomed by the President of Zaïre, General Mobutu Sese Seko, in a hard-hitting speech that set the tone for the discussions and sessions. Extracts from this are opposite. A striking paper by Dr R. F. Dasmann is reprinted, on page 281.

A new development in the SSC's programme is the concentrated attack on the problem of endangered plants - of which there are thought to be some 20,000. How this enormous task is being tackled was described by Grenville Lucas in a paper, extracts from which are reprinted on page 257.

\section{IUCN Executive Board}

President: Professor D. J. Kuenen, Netherlands

Vice-Presidents: Professor A. G. Bannikov, USSR; Eskandar Firouz, Iran; Dr D. F. McMichael, Australia; Dr Lee M. Talbot, U.S.A.; Dr David P. S. Wasawo, Kenya.

Members: Professor P. Aguesse, France; Dr E. O. A. Asibey, Ghana; Robert E. Boote, UK; William G. Conway, USA; Dr Martin H. Edwards, Canada; Y. Fukushima, Japan; Professor Pierre Goeldlin, Switzerland; Dr A. Inozemtsev, USSR; Professor M. Kassas, Egypt; Dr Ashok Khosla, India; Ing. E. Mondolfi, Venezuela; Dr Meuma Ngoy Toka, Zaïre; Andres Rozental, Mexico; Professor Otto Soemarwoto, Indonesia; Lic. G. Stutzin, Chile. 